\section{Ethics group to look at energy, water and the information society}

[LONDON] Unesco's World Commission on the Ethics of Scientific Knowledge and Technology (COMEST) is due to prepare its contribution to the World Conference on Science at its first meeting, being held in Oslo this week at the invitation of the Norwegian government.

During the three-day meeting, COMEST will undertake what Unesco describes as "a first exchange of views on ethics and the information society". Public round-table discussions are also planned, which will bring together representatives of international and non-governmental organizations, as well as players from the public and private sectors. The round-table themes will be ethics and energy, ethics and free water resources, and the ethics of the information society.

Such areas, says Unesco, reflect COMEST's mandate to serve "as an intellectual forum for the exchange of ideas and experience; to detect the early signs of risk situations; to fulfil an advisory role for decision-makers, and to promote dialogue between scientific communities, decisionmakers and the public".

COMEST was set up in May 1988 by Unesco, with 18 members appointed by the director-general, to advise the organization and to serve as an intellectual forum for the exchange of ideas and experiences and to promote dialogue between scientific communities, decision-makers and the public. COMEST chair and former president of Iceland, Vigdís Finnbogadóttir, is due to address the opening session of the meeting. Report: http://helix.nature.com/wcs/a27.htm

\title{
How biotechnology could be Africa's route to riches
}

[HAMMAMET, TUNISIA] Africa-wide investment in biotechnology could be the continent's route to prosperity, says Thomas Odhiambo, founder and outgoing president of the African Academy of Sciences.

Addressing the academy's fifth general conference in Hammamet, Tunisia, this week, after 13 years at the head of the organization, Odhiambo said that African scientists and entrepreneurs need to find "niche areas" where their investments have a stronger chance of succeeding - such as the commercialization of genetic resources.

Odhiambo said that, while many countries struggle to find products and markets for their nascent biotechnology industries, Africa has a genuine competitive advantage, given that it owns the world's largest stock of plants with known medicinal properties.

$\mathrm{He}$ added that scientists and policymakers in Africa need to modify their approach to biotechnology, from seeing it as primarily a source for the continent's future food needs to building a major knowledge industry. Africa's transformation from a recipient of development aid to a major competitor in world markets relies on such a change, said Odhiambo.

The outgoing president's comments are expected to form the basis of one of the key recommendations from the Africa region for the World Conference on Science in Budapest. The Tunisian conference's recommendations for the Budapest meeting, known as the 'Tunis Declaration', are expected to be finalized next week.

Odhiambo's suggestions indicate a more proactive response from leading African scientists to bioprospecting by overseas multinationals. Until now, the region's leading scientists had called for changes to global intellectual property legislation as the main route to protecting indigenous knowledge.

His comments were broadly echoed by Ali Mazrui, professor emeritus of African studies at Cornell University, New York. But Mazrui warned the academy's fellows not to repeat past mistakes when attempting to embrace new technologies.

The poor state of research and higher education in Africa, Mazrui contended, had come about partly because the architects of these institutions had modelled them mostly on what they saw in Western Europe, taking little account of different linguistic and cultural environments. "An African renaissance somehow needs a 'reindigenizing' component," Mazrui told the conference.

The academy's new president is Mohammad Hassan, a mathematician and executive director of the Third World Academy of Sciences. Hassan says that one of his first tasks as president will be to persuade African governments to make more use of their senior scientists, for example through advisory committees in the areas of water management, agriculture and drought - the continent's three most pressing problems.

Another priority, says Hassan, will be to encourage centres of research excellence in Africa to help build up similar centres in neighbouring countries by passing on advice and engaging in collaborative projects. Full report: http://helix.nature.com/wcs/a26.htm

\section{Virtual labs offer chance for South to beat the science brain drain}

[LONDON] Virtual laboratories, based on the extensive use of electronic communications, could be a valuable device for combating the brain drain from the South, according to three researchers at Abdus Salam International Centre for Theoretical Physics in Trieste, Italy.

But Enrique Canessa, Fulvio Postogna and Sandro Radicella add that developing countries have a long way to go before they can fully exploit the Internet's potential.

An analysis of articles published on the Los Alamos e-preprint archives in condensed-matter physics and high-energy physics (theory), revealed 88 and 50 e-preprints respectively from groups of authors working in different countries. In each archive, however, only one e-preprint has resulted from a collaboration between developing country institutions alone.

"It seems unlikely that virtual laboratories will be widely adopted by developing country scientists in the near future," say the authors. One reason is a lack of adequate computing literacy in the academic communities of countries new to the Internet. Other important factors are human diversity and age differences.

"Participation in interactive sessions from the South should make it easier to do science, not become another barrier to surpass," say the authors. They hope to see the administration of 'virtual laboratories' simplified "so they can be run by scientists for scientists in their own countries".

But they note that the limited bandwidth of the few available telecommunication lines in developing countries causes congestion and often makes access too slow to use.

They recommend that Internet access grants or subsidies should be made available to scientists from less-privileged countries. "The 'virtual lab' approach could become a worthwhile service that helps to reduce scientific isolation while filling the need to transfer knowledge to the South in an unprecedented way," they conclude. Full text: http://helix.nature.com/wos/c12.html 